\title{
Effect of zirconia in the density and ionic conductivity properties of $\mathrm{Bi}_{4} \mathrm{~V}_{1.8} \mathrm{Cu}_{0.1} \mathrm{Zn}_{0.1} \mathrm{O}_{10.7}$ compound
}

\author{
Silva, AB ${ }^{1}$; Rueda-P,Jorge-E ${ }^{2}$, Gomes K. Q. ${ }^{3}$ \\ ${ }^{1}$ Department of Materials Engineering, University of São Paulo, São Carlos-SP, Brazil. \\ ${ }^{2}$ Grupo Óptica Moderna, Departamento de Física, Universidad de Pamplona, Colombia. \\ ${ }^{3}$ Department of Engineering and Computer Science, North University Center of Espírito Santo, São \\ Mateus-ES, Brazil.
}

\begin{abstract}
Ceramics based bismuth vanadate are conductors of oxygen ions and they are used as solid electrolytes in pressure sensors and fuel cells. These materials operate at temperatures above $700{ }^{\circ} \mathrm{C}$. At high temperatures, the bismuth-vanadium oxide $\left(\mathrm{Bi}_{4} \mathrm{~V}_{2} \mathrm{O}_{11}\right)$ has a $\gamma$-phase with a large number of oxygen vacancies that favors the ionic conductivity. The $\gamma$-phase of the $\mathrm{Bi}_{4} \mathrm{~V}_{2} \mathrm{O}_{11}$ was stabilized at room temperature by partial substitution of vanadium $\left(\mathrm{V}^{5+}\right)$ ions by cuprum $\left(\mathrm{Cu}^{2+}\right)$ and zinc $\left(\mathrm{Zn}^{2+}\right)$ ions to provide high ionic conductivity values between 100 and $400^{\circ} \mathrm{C}$. Thus, polycrystalline samples of $\mathrm{Bi}_{4} \mathrm{~V}_{1.8} \mathrm{Cu}_{0.1} \mathrm{Zn}_{0.1} \mathrm{O}_{10.7}$ were obtained after $4 \mathrm{~h}$ sintering at $800{ }^{\circ} \mathrm{C}$. Investigations were made about densification process and ionic conductivity related to the effect of addition of the yttria-stabilized zirconia $\left(\mathrm{Zr}_{0.88} \mathrm{Y}_{0.12} \mathrm{O}_{1.94}\right)$.
\end{abstract}

Keywords: Bismuth-vanadium oxide, yttria-stabilized zirconia, oxygen ion conductor.

\section{Efecto de la zirconia en las propiedades densidad y conductividad iónica del compuesto $\mathrm{Bi}_{4} \mathrm{~V}_{1.8} \mathrm{Cu}_{0.1} \mathrm{Zn}_{0.1} \mathrm{O}_{10.7}$}

\section{Resumen}

Cerámicas de vanadato de bismuto son conductores de iones de oxígeno y se utilizan como electrolitos sólidos en los sensores de presión y pilas de combustible. Estos materiales funcionan a temperaturas superiores a $700{ }^{\circ} \mathrm{C}$. A altas temperaturas, el óxido de bismuto-vanadio $\left(\mathrm{Bi}_{4} \mathrm{~V}_{2} \mathrm{O}_{11}\right)$ tiene una fase- $\gamma$ con un gran número de vacantes de oxígeno que favorece la conductividad iónica. La fase- $\gamma$ del $\mathrm{Bi}_{4} \mathrm{~V}_{2} \mathrm{O}_{11}$ fue estabilizado a temperatura ambiente por sustitución parcial de iones de vanadio $\left(\mathrm{V}^{5+}\right)$ por iones de cobre $\left(\mathrm{Cu}^{2+}\right)$ y iones de zinc $\left(\mathrm{Zn}^{2+}\right)$ para proporcionar valores de conductividad iónica alta entre $100^{\circ} \mathrm{C}$ y $400^{\circ} \mathrm{C}$. Por lo tanto, las muestras policristalinas de $\mathrm{Bi}_{4} \mathrm{~V}_{1.8} \mathrm{Cu}_{0.1} \mathrm{Zn}_{0.1} \mathrm{O}_{10.7}$ se obtuvieron después de la sinterizarlas durante 4 horas a $800^{\circ} \mathrm{C}$. Se estudió el proceso de densificación y la conductividad 
28

iónica relacionada con el efecto de la adición de la zirconia estabilizada con itria (Zro.88 $\mathrm{Y}_{0.12} \mathrm{O}_{1.94)}$.

Palabras clave: Óxido de Bismuto-Vanadio, zirconia estabilizada con itria, conductor de iones de oxígeno.

*Para citar este articulo: Silva, AB; Rueda-P,Jorge-E ; Gomes K. Q. Effect of zirconia in the density and ionic conductivity properties of $\mathrm{Bi}_{4} \mathrm{~V}_{1.8} \mathrm{Cu}_{0.1} \mathrm{Zn}_{0.1} \mathrm{O}_{10.7}$ compound.Revista Bistua.2015.13(1):27-34

+ Autor para el envió de correspondencia y la solicitud de las separatas: Silva, AB.Department of Materials Engineering, University of São Paulo, São Carlos-SP, Brazil, e-mail: aborges.abs@gmail.com 
29

\section{Introduction}

The $\mathrm{Bi}_{4} \mathrm{~V}_{2} \mathrm{O}_{11}$ has a $\gamma$-phase at high temperature $\left(700{ }^{\circ} \mathrm{C}\right)$ that exhibits a relatively high conductivity when compared to others conventional ionic conductors, as $\mathrm{CeO}_{2}$ and $\mathrm{ZrO}_{2}$. Partial substitutions of metal ions, such as ions of $\mathrm{Cu}, \mathrm{Ni}, \mathrm{Zn}$, etc., by vanadium can stabilize the $\gamma$-phase of the $\mathrm{Bi}_{4} \mathrm{~V}_{2} \mathrm{O}_{11}$ at room temperature and they have been found to result in materials exhibiting high ionic conductivities ${ }^{1,2,3,4}$ Thus, the materials of the called BIMEVOX family are considerably attractive to use in ionic conductors at low temperatures (300 to $400 \stackrel{\circ}{\circ}$ ); to applications as oxygen gas sensors.

On this work, the $\gamma$-phase of the $\mathrm{Bi}_{4} \mathrm{~V}_{2} \mathrm{O}_{11}$ was stabilized at low temperature by substitutions of $\mathrm{Cu}^{2+}$ and $\mathrm{Zn}^{2+}$ ions by $\mathrm{V}^{5+}$ ions in molar fraction of $5 \%$. These partial substitutions formatted the $\mathrm{Bi}_{4} \mathrm{~V}_{1.8} \mathrm{Cu}_{0.1} \mathrm{Zn}_{0.1} \mathrm{O}_{10.7} \quad$ compound which was sintered for $4 \mathrm{~h}$ at $800{ }^{\circ} \mathrm{C}$ in format of ceramics pellet. In addition, the yttria-stabilized zinconia ( $\left.\mathrm{Zr}_{0.88} \mathrm{Y}_{0.12 \mathrm{O}} \mathrm{O}_{1.94}\right)$ was added to the doped bismuth-vanadium oxide in mass fraction of $5 \%, 10 \%, 15 \%$ and, $20 \%$. Density measurements was made to verify the densification obtained of the material by the sintering process used in this work. The ionic conductivity investigation of the $\mathrm{y}-\mathrm{Bi}_{4} \mathrm{~V}_{1.8} \mathrm{Cu}_{0.1} \mathrm{Zn}_{0.1} \mathrm{O}_{10.7}$ with and without $\mathrm{Zr}_{0.88} \mathrm{Y}_{0.12} \mathrm{O}_{1.94}$ was realized by impedance spectroscopy method.

\section{Experimental part}

The commercial oxides used as basic substances to obtaining of $\mathrm{Bi}_{4} \mathrm{~V}_{2} \mathrm{O}_{11}$ compound were: bismuth oxide $\left(\mathrm{Bi}_{2} \mathrm{O}_{3}\right)$ from Victoria Química-São Paulo/BR and vanadium oxide $\left(\mathrm{V}_{2} \mathrm{O}_{5}\right)$ from Vetec-Rio de Janeiro/BR. And the commercial oxides used as doping agents to obtaining of BICUZNVOX were: $\mathrm{CuO}$ from Mallinckrodt-Missouri/USA and $\mathrm{ZnO}$ from Merck. In addition, was used the commercial oxide of yttria-stabilized zirconia $12 \%$ in moll $\left(\mathrm{Zr}_{0.88} \mathrm{Y}_{0.12} \mathrm{O}_{1.94}\right.$ or 12YSZ) from Toyo Soda to increasing the densification of the samples.

Samples were prepared by mixing appropriate proportions of the precursors oxides ${ }^{5}$ and their compositions were established after an analysis of literature data observing $^{1,2,6}$ the compositions exhibit the best results of electrical and physics (density) properties. These compositions were specified as BICUZNVOX.10 for the $\mathrm{Bi}_{2} \mathrm{~V}_{0.9} \mathrm{Cu}_{0.05} \mathrm{Zn}_{0.05} \mathrm{O}_{5.35}$ (or $\mathrm{Bi}_{4} \mathrm{~V}_{1.8} \mathrm{Cu}_{0.1} \mathrm{Zn}_{0.1} \mathrm{O}_{10.7}$ ) sample and for samples of the $\mathrm{Bi}_{2} \mathrm{~V}_{0.9} \mathrm{Cu}_{0.05} \mathrm{Zn}_{0.05} \mathrm{O}_{5.35}$ with addition of $5 \%, 10 \%, 15 \%$, and $20 \%$ of zirconia mass fraction as being $\left(\mathrm{Cu}_{0.05} \mathrm{Zn}_{0.05}\right)_{1-\mathrm{x}}(12 \mathrm{YSZ})_{\mathrm{x}}$ with $\mathrm{X}=0.05 ; 0.10 ; 0.15$ and 0.20 .

Polycrystalline samples of BICUZNVOX.10 in monolithic pellets 
30

format were obtained by sintering for $4 \mathrm{~h}$ at $800{ }^{\circ} \mathrm{C}$ after a study of densification ${ }^{5}$. The sintering was made in the muffle EDGON 1P 1800 model. Likewise, for the investigation of the effect caused by addition of yttria-stabilized zirconia in the ionic conductivity and densification of the material, the samples of BICUZNVOX.10 with 12YSZ were sintered in the same temperature and time (at $800^{\circ} \mathrm{C}$ for $4 \mathrm{~h}$ ).

Electrical impedance measurements of pellets of the $\left(\mathrm{Cu}_{0.05} \mathrm{Zn}_{0.05}\right)_{1}$ $x(12 Y S Z) x$ and BICUZNVOX.10 were realized by Impedance Analyzer Hewlett Packard 4192A LF Model with the Impedance Measurements software using the appropriate input parameters ${ }^{[5]}$. It was used the frequency range of 5 to $13 \times 10^{6} \mathrm{~Hz}$ and the temperature range of 100 to $400 \stackrel{\circ}{\circ}$ with $50 \stackrel{\circ}{\circ}$ increment. Data Analysis software was used to the inquiry of impedance values.

\section{Results and discussion}

\section{Physics (density) characterization}

The best results of densification for BICUZNVOX.10 were obtained at 800 ${ }^{\circ} \mathrm{C}$ for $4 \mathrm{~h}$ of sintering. With these results was realized a study of the effect of yttria-stabilized zirconia (12YSZ) about the BICUZNVOX.10 compound densification to mass fractions of $5 \%, 10 \%, 15 \%$ and $20 \%$ (see Figure 1).

The geometric density of the BICUZNVOX.10 increases with the increasing of zirconia quantity. Low variation was obtained in the correlation factor (Density vs Zirconia mass) of the sintered samples relative to samples not sintered (11.4754\%). In other words, the increased density sintered samples in $5.1498 \%$ compared to the same non-sintered samples. This observation is a normal comportment similar to the values found in the literature $e^{7,8,9,10,11}$. Zirconium oxide, besides be an oxygen ion conductor, has a high refractory property so as does not react with the liquid phase formed in the BICUZNVOX.10 compound and it is responsible for the densification process.

\section{Electrical characterization}

Impedance measurements results were used to verify the material behavior related to ionic conductivity. In the impedance spectroscopy diagrams, it was possible to observe two contributions present to conductivity process: by grain boundary and grain for some test temperatures. However, there is no possibility to discern both contributions in others temperatures of test. The total resistance of the specimens at different temperatures 
31

was calculated from the point of intersection of the impedance spectrum with the real axis of the impedance spectroscopy diagram.

The results obtained of ionic conductivity showed a decreasing of impedance with the increasing of temperature (Figure 2(a) and 2(b)). This phenomenon is due to excitation of the charge carries, ions, around of its equilibrium positions in the crystalline lattice.

The Arrhenius plots for the conductivity behavior of solid solution samples are shown in the Figure 3. This confirms the charge transport process is thermally activated. In addition, there was no significant difference between the activation energy values of the BICUZNVOX.10 samples with the increasing of zirconia quantity. Activation energy values in this work (approximately $0.26 \mathrm{eV}$ ) are smaller than literature's values found ${ }^{7,8}$. These values indicate, therefore, which the conduction mechanism is attributed predominantly by electrons hopping ${ }^{12}$.

It was also possible to analysis how the ionic conductivity behaved when the yttria-stabilized zirconia was added. Zirconium oxide has a high refractory property that increasing the density of the BICUZNVOX.10 but, it not exhibits a good conductivity at low temperatures $^{7}$ and the ionic conductivity of bismuth vanadate oxide, therefore, not showed high values (Figure 4).

In this case, zirconia oxide behaves as impurity in the material to difficult the oxygen ions passage. However, these results of ionic conductivity obtained in this work are in good agreement with those found in the literature. Table 1 compare some ionic conductivity values with some of literature ${ }^{1,13,14,15,16}$ at $300 \stackrel{\circ}{ } \mathrm{C}$.

\section{Conclusions}

The $\gamma$-phase of $\mathrm{Bi}_{4} \mathrm{~V}_{2} \mathrm{O}_{11}$ could be stabilized at room temperature by partial substitutions of $\mathrm{Cu}^{2+}$ and $\mathrm{Zn}^{2+}$ ions by $\mathrm{V}^{5+}$ ions. Thus, the effect caused by addition of yttria-stabilized zirconia, $\quad \mathrm{Zr}_{0.88} \mathrm{Y}_{0.12} \mathrm{O}_{1.94}, \quad$ was investigated in the densification process and ionic conductivity of the $\mathrm{Bi}_{4} \mathrm{~V}_{1.8} \mathrm{Cu}_{0.1} \mathrm{Zn}_{0.1} \mathrm{O}_{10.7}$ samples. The yttria-stabilized zirconia does not react with the constituents oxides and permits the densification of the samples. However, the ionic conductivity decreases with the increasing of zirconia quantity. The activation energy not showed significative variation with the increasing of zirconia quantity. In addition, the samples with 12YSZ exhibited low activation energy values, about $0.26 \mathrm{eV}$. 
32

\section{References}

1. Vannier, R.N. et al. Double substitutions in $\mathrm{Bi}_{4} \mathrm{~V}_{2} \mathrm{O}_{11}$. Solid State lonics. 1994; v. 70/71, 248-252.

2. Al-Areqi, N. A.S., and Beg, S. Studies in composition and temperature dependence of phase stability in the $\mathrm{Bi}_{4} \mathrm{Ag}_{\mathrm{x}} \mathrm{V}_{2-}{ }_{\mathrm{x}} \mathrm{O}_{11-(2 \mathrm{x})-\delta}$ system and their influence on the oxide ion performance. Phase Transitions. 2012; Vol. 85, No. 3, 255-263.

3. Sut, J., Borah, L., Pandey, A. Synthesis, structure and electrical conductivity of Li-substituted $\mathrm{Bi}_{4} \mathrm{~V}_{2} \mathrm{O}_{11}$ solid electrolyte. Int. J. of Innovative Res. \& Dev. 2012; Vol 1, Issue 7, 181-185.

4. Preux, N., Rolle, A., and Vannier, R. N. Electrolytes and ion conductors for solid oxide fuel cells (SOFCs). Func. Mat. for Sustainable Energy App. 2012; Woodhead Publishing Limited, 370-401.

5. Silva, A. B. Condutividade elétrica dos compostos BIMEVOX com adição de zircônia parcialmente estabilizada. Dissertation submitted to the graduate program in Materials Engineering. 1999; São Carlos : UFSCar, 94 p.

6. Fouletier, J. et al. Electrical anisotropy and electronic conductivity of BIMEVOX electrolytes. European Ceramic Society. 1996; 37-45.

7. Krok, F. et al. Influence of preparation procedure on some physical properties of BICUVOX. Mat. Science and Eng. 1993; v. B21, 70-76.

8. Simner, S.P. et al. Synthesis, densification, and conductivity characteristics of BICUVOX oxygen-ionconducting ceramics. J. Am. Ceram. Soc. 1997 ; v. 80, n. 10, 2563-2568.

9. Simner, S.P. et al. Solution processing approaches for solid electrolytes and electrode materials. J. Mater. Res. 1998; v. 13 , n. $4,866-874$.

10. Muller, C. et al. Lattice vibrations and order-disorder transition in the oxide anion conductor BICOVOX.15: a neutron thermodiffractometry study. Solid State lonics. 1998; v. 111, 27-36.

11. Shantha, K., and Varma, K.B.R. Fabrication and characterization of grainoriented bismuth vanadate ceramics. Mat. Res. Bulletin. 1997; v. 32, n. 11, 1581-1591.

12. Radhapiyari, L., Phanjoubam, S., Sarma, H. N. K., Prakash, C. Influence of $\mathrm{Co}^{+2}$ on the electrical and magnectic properties of $\mathrm{Li}-\mathrm{Sb}$ ferrites. Materials Letters. 2000; 44, 65-69.

13. LARUZE, $S$. et al. Composition dependence of oxide anion conduction in the BIMEVOX family. Solid State Ionics. 1996; v. 90, p. 117-123.

14. YAN, J., and GREENBLATT, M. Ionic conductivities of $\mathrm{Bi}_{4} \mathrm{~V}_{2-x} \mathrm{M}_{x} \mathrm{O}_{11-x}$ $(\mathrm{M}=\mathrm{Ti}, \mathrm{Zr}, \mathrm{Sn}, \mathrm{Pb})$ solid solutions. Solid State Ionics. 1995; v. 81, p. 225-233.

15. FAFILEK, G., and BREITER, M.W. Instrumentation for ac four-probe measurements of large impedances. J. of Electroan. Chem. 1997; v. 430, p. 269278.

16. LEE, C.K., and WEST, A.R. Thermal behavior and polymorphism of BIMEVOX oxide ion conductors including the new materials: $\mathrm{Bi}_{4} \mathrm{~V}_{2} \mathrm{O}_{11}: \mathrm{M} ; \mathrm{M}=\mathrm{La}, \mathrm{Y}, \mathrm{Mg}, \mathrm{B}$. 
Solid State lonics. 1996 ; v. $86-88$, p. 235239.

Acknowledgement:

UFSCar.

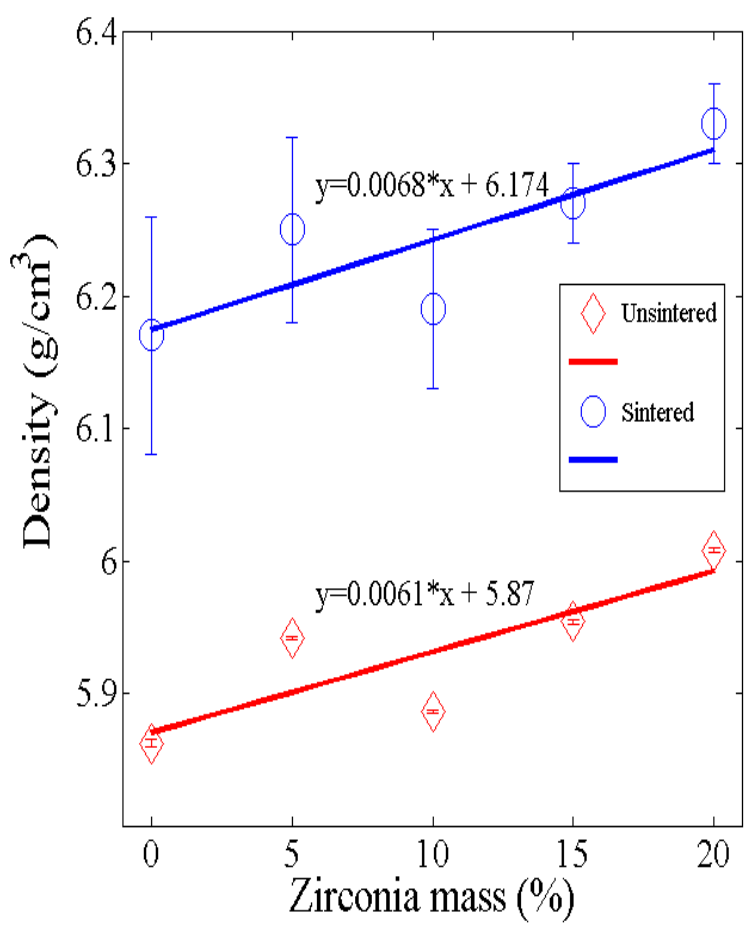

Figure 1. Densification behavior of the BICUZNVOX.10 material related to addition of $\mathrm{Zr0} .88 \mathrm{Y} 0.12 \mathrm{O} 1.94 \mathrm{(5 \%}, 10 \%, 15 \%$ and $20 \%$ ) to the samples sintered at $800{ }^{\circ} \mathrm{C}$ for $4 \mathrm{~h}$
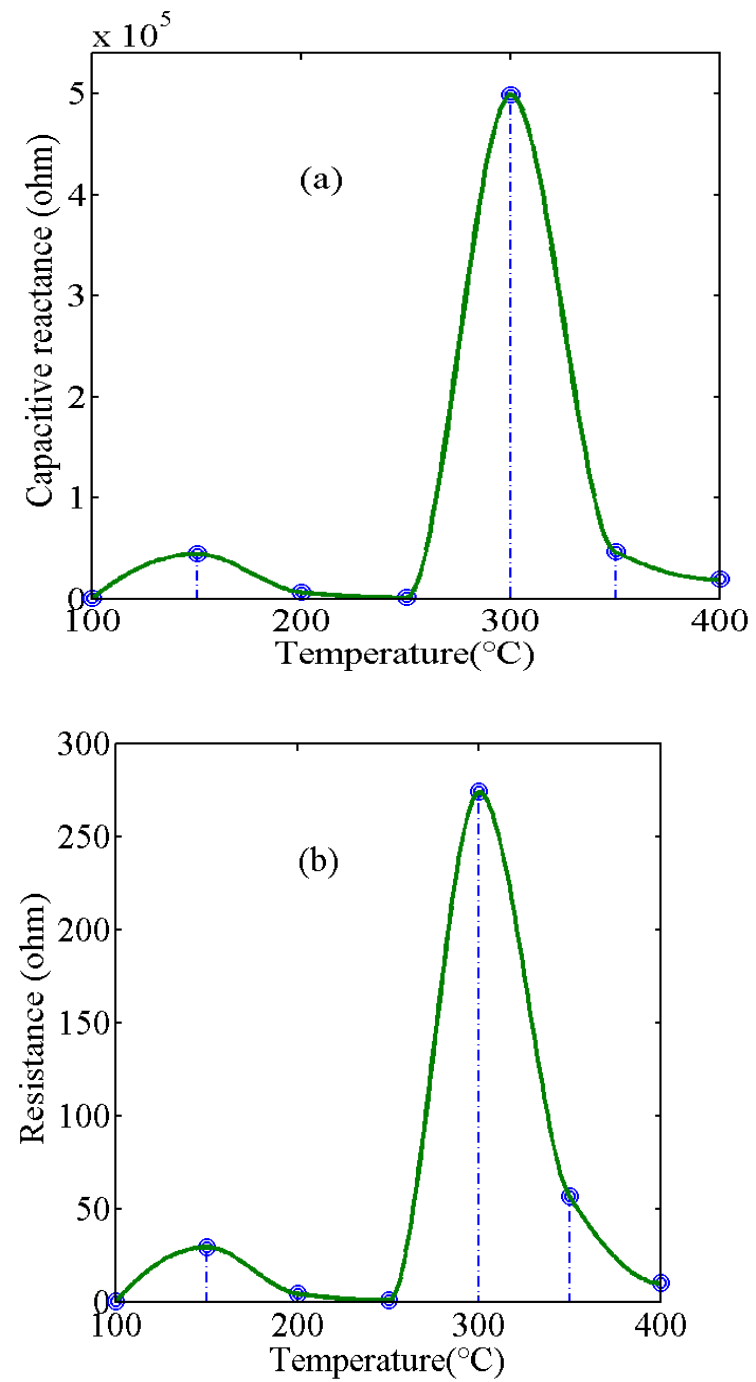

Figure 2. Behavior analyzes about electrical properties by temperature of the BICUZNVOX.10 samples: (a) capacitive reactance and (b) resistance. 


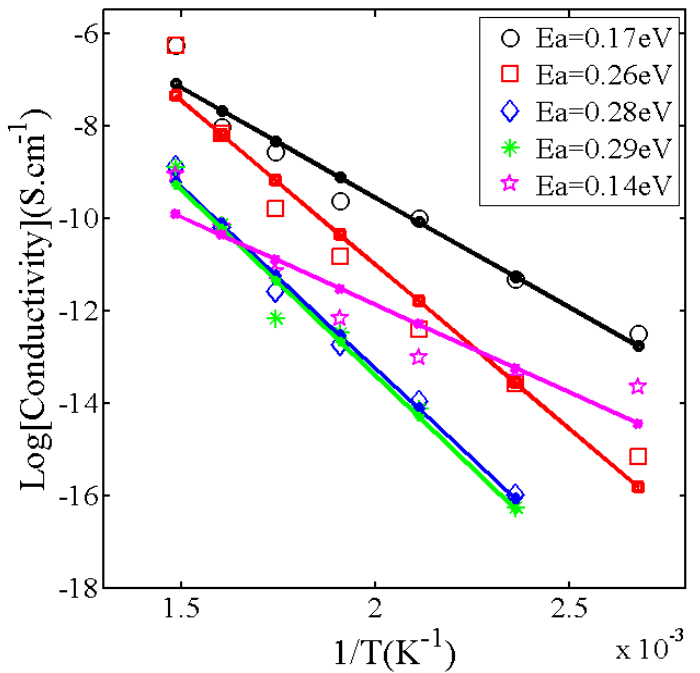

Figure 3. Ionic conductivity of the BICUZNVOX.10 samples with: (o) $0 \%,(\square)$ $5 \%,(\diamond) 10 \%,(15 \%$, and $(\%) 20 \%$ mass of yttria-stabilized zirconia sintered at $1073 \mathrm{~K}$ for $4 \mathrm{~h}$.

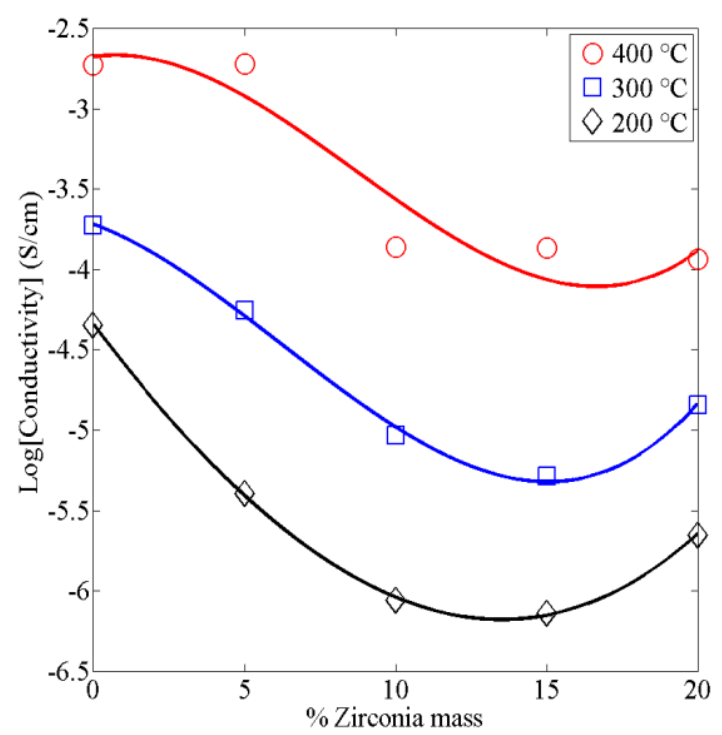

Figure 4. Ionic conductivity of BICUZNVOX.10 with addition of 12 YSZ $(0 \%$, $5 \%, 10 \%, 15 \%$ and $20 \%$ ) sintered at $800 \stackrel{\circ}{C}$ for $4 \mathrm{~h}$.
Table 1. Ionic conductivity values for several solid electrolytes.

\begin{tabular}{cc}
\hline Samples & $\begin{array}{c}\sigma(\mathrm{S} / \mathrm{cm}) \text { at } 300 \\
{ }^{\circ} \mathrm{C}\end{array}$ \\
\hline $\mathrm{Bi}_{2} \mathrm{~V}_{0,90} \mathrm{Cu}_{0,05} \mathrm{Zn}_{0,05} \mathrm{O}_{5,35}\left(^{*}\right)$ & $1.88 \times 10^{-4}$ \\
$\left(\mathrm{Cu}_{0.05} \mathrm{Zn}_{0.05}\right)_{0.95}(12 \mathrm{YSZ})_{0.05}\left(^{*}\right)$ & $5.56 \times 10^{-5}$ \\
$\left(\mathrm{Cu}_{0.05} \mathrm{Zn}_{0.05}\right)_{0.90}(12 \mathrm{YSZ})_{0.10}\left(^{*}\right)$ & $9.33 \times 10^{-6}$ \\
$\left(\mathrm{Cu}_{0.05} \mathrm{Zn}_{0.05}\right)_{0.85}(12 \mathrm{YSZ})_{0.15}\left(^{*}\right)$ & $5.15 \times 10^{-6}$ \\
$\left(\mathrm{Cu}_{0.05} \mathrm{Zn}_{0.05}\right)_{0.80}\left(12 \mathrm{YSZ}_{0.20}\left(^{*}\right)\right.$ & $1.43 \times 10^{-5}$ \\
$\mathrm{Bi}_{2} \mathrm{~V}_{0.90} \mathrm{~W}_{0.10} \mathrm{O}_{5.35}{ }^{[13]}$ & $7.94 \times 10^{-5}$ \\
$\mathrm{Bi}_{2} \mathrm{~V}_{0.90} \mathrm{Zr}_{0.10} \mathrm{O}_{5.35}{ }^{[14]}$ & $6.30 \times 10^{-5}$ \\
$\mathrm{Bi}_{2} \mathrm{~V}_{0.90} \mathrm{Cu}_{0.05} \mathrm{Zn}_{0.05} \mathrm{O}_{5.35}{ }^{[1]}$ & $3.16 \times 10^{-3}$ \\
$\mathrm{Bi}_{2} \mathrm{~V}_{0.90} \mathrm{Cu}_{0.05} \mathrm{Ni}_{0.05} \mathrm{O}_{5.35}{ }^{[1]}$ & $2.51 \times 10^{-3}$ \\
$\mathrm{Bi}_{2} \mathrm{~V}_{0.90} \mathrm{Ni}_{0.05} \mathrm{Zn}_{0.05} \mathrm{O}_{5.35}{ }^{[1]}$ & $1.78 \times 10^{-3}$ \\
$\mathrm{Bi}_{2} \mathrm{~V}_{0.90} \mathrm{Cu}_{0.05} \mathrm{Mo}_{0.05} \mathrm{O}_{5.35}{ }^{[1]}$ & $1.33 \times 10^{-3}$ \\
$\mathrm{Bi}_{2} \mathrm{~V}_{0.90} \mathrm{Cu}_{0.10} \mathrm{O}_{5.35}{ }^{[15]}$ & $2.32 \times 10^{-3}$ \\
$\mathrm{Bi}_{2} \mathrm{~V}_{0.90} \mathrm{Mg}_{0.10} \mathrm{O}_{5.35}{ }^{[16]}$ & $1.10 \times 10^{-3}$ \\
\hline
\end{tabular}

* Values found in this work.

Silva, AB:

Department of Materials Engineering, University of São Paulo, São Carlos-SP, Brazil

Rueda-P,Jorge-E:

Ph.D. Investigador Asociado. Profesor Titular.Grupo Óptica Moderna.Departamento de Física, Universidad de Pamplona, Colombia.

Gomes K. Q:

Department of Engineering and Computer Science, North University Center of Espírito Santo, São Mateus-ES, Brazil. 